\title{
CHARACTERISTICS OF NON-CHOLERA VIBRIOS ISOLATED FROM PATIENTS WITH DIARRHOEA
}

\author{
B. D. Chatterjee, S. L. Gorbach* and K. N. Neogy \\ School of Tropical Medicine, Calcutta 12, India
}

THE vibrios that have similar biochemical reactions to those of Vibrio cholerae and are not agglutinable by $V$. cholerae $\mathrm{O}$-subgroup I antiserum have been designated non-cholera vibrios (NCV), non-agglutinable or non-agglutinated vibrios (NAG), choleriform vibrios (Pollitzer, 1959) and water vibrios (McIntyre and Feeley, 1965). In India and Pakistan, the classical home of cholera, NCV have been associated with the "full-blown cholera syndrome" (Carpenter et al., 1965; Lindenbaum et al., 1965). The clinical features of NCVdiarrhoea range from a cholera-like disease with rice-water stools to mild gastro-enteritis (McIntyre and Feeley; Aldová et al., 1968). However, the aetiological relation remains to be proven. Infection with $V$. cholerae is known to cause a rise in the serum agglutinins in 94 per cent. of cases (Sack et al., 1966). On the other hand, NCV infection does not consistently give rise to a detectable immunological response (Lindenbaum et al.; McIntyre et al., 1965; Aldová et al.).

Heiberg (1936) classified NCV into six groups, and two additional groups have recently been proposed by Smith and Goodner (1965). Heiberg groups are conventionally determined on the basis of fermentation reactions with the sugars mannose, sucrose and arabinose. However, several other biochemical characters of the Heiberg groups have not been described in the literature. The present work was planned to investigate the biological characters of NCV strains associated with choleraic diarrhoea in Calcutta according to their Heiberg groups.

\section{MATERIALS AND METHODS}

During 1967-68 we investigated patients with acute diarrhoea suggestive of cholera who had not received prior antibiotic therapy and were admitted to the Johns Hopkins Unit of the Infectious Diseases Hospital, Calcutta. Shortly after admission, portions of a faecal sample from each patient were plated on TCBS Agar (BBL), bile salt agar and MacConkey's Agar (Difco); the plates were incubated overnight at $37^{\circ} \mathrm{C}$. The TCBS Agar is a highly selective medium for the isolation of vibrios. It contains yeast extract $5.0 \mathrm{~g}$, peptone $10.0 \mathrm{~g}$, sodium citrate $10.0 \mathrm{~g}$, sodium thiosulphate $10.0 \mathrm{~g}$, ox gall $5.0 \mathrm{~g}$, sodium chulate $3.0 \mathrm{~g}$, sucrose $20.0 \mathrm{~g}$, sodium chloride $10.0 \mathrm{~g}$, iron citrate $1.0 \mathrm{~g}$, thymol blue $0.04 \mathrm{~g}$, bromthymol blue $0.04 \mathrm{~g}$ and agar $14.0 \mathrm{~g}$ in a total volume of 1 litre at $p \mathrm{H} 8 \cdot 6 \pm 0 \cdot 2$. The colonies of vibrios are yellow in the case of sucrose fermenters $\{$ i.e., for Heiberg groups (HG) I, II $\}$ and green in the case of non-fermenters of sucrose (i.e., for HG V, VII, VIII). On TCBS medium the growth of other organisms such as coliforms and members of the Comamonas, Pseudomonas and Aeromonas genera is inhibited. On bile salt agar plates, NCV colonies appear slightly more turbid and a little more elevated than those of $V$. cholerae and $V$. eltor. We also attempted to find vibrios by examining slow-fermenters of lactose as well as lactose non-fermenting colonies that grew on MacConkey's Agar.

In 38 cases NCV were detected as the only pathogen; faeces from nine other patients yielded NCV in association with $V$. eltor. Other enteric pathogens were not detected in any of these patients. After checking their colonial morphology we subjected the 47 strains of $\mathrm{NCV}$ isolated from the 47 patients to two series of tests.

The preliminary examinations included observations on the Gram-staining reaction, motility test (Cruickshank, 1965), oxidase activity (Kovacs, 1956) and the string test (Smith, 1958); the smoothness or roughness of colonies was determined from the stability of

Received 18 Dec. 1969; accepted 27 Feb. 1970.

* Present address: Associate Professor of Medicine, University of Illinois, at the Medical Center, Chicago, Illinois 60680 . 
bacterial suspensions in $0 \cdot 3,0 \cdot 5,0.7$ and 0.85 per cent. $\mathrm{NaCl}$ in distilled water and also in 1 in 1000 acriflavine (test modified from that of Wilson and Miles, 1964); we also used the O-F test (Hugh and Leifson, 1953) and we studied $\mathrm{H}_{2} \mathrm{~S}$ production by NCV grown in TSI medium (Cowan and Steel, 1966); Møller's (1955) tests for decarboxylase reactions with arginine, lysine and ornithine were done with Difco base. The strains were tested for agglutinability with $V$. cholerae $\mathrm{O}$-subgroup I antiserum.

The NCV identified by the above methods were subjected to a further battery of tests. Fermentation of glucose, mannitol, lactose, mannose, sucrose, arabinose, melibiose, cellobiose, salicin, dulcitol, inositol, sorbitol, rhamnose and raffinose was tested for in Broth Base Phenol Red (Difco) with the addition of 1 per cent. of the appropriate sugar. The strains were allocated to Heiberg groups (HG) when they were freshly isolated according to the modified procedure of Smith and Goodner. Other tests included formation of pellicle in

Table I

Heiberg groups of the 47 NCV strains isolated in Calcutta and the significant sugar fermentation reactions observed

\begin{tabular}{c|c|c|c|c}
\hline \multirow{2}{*}{ Heiberg group } & \multicolumn{2}{|c|}{ Result of fermentation test with } & \multicolumn{2}{c}{$\begin{array}{c}\text { Number of } \\
\text { strains }\end{array}$} \\
\cline { 2 - 4 } & sucrose & mannose & arabinose & \\
\hline II & + & + & - & 14 \\
III & + & - & - & 16 \\
III & + & + & + & 0 \\
V & + & - & + & 0 \\
VI & - & + & - & 2 \\
VII & - & - & - & 1 \\
VIII & - & + & + & 13 \\
\hline
\end{tabular}

overnight broth culture, indole test (after culture in peptone water for $48 \mathrm{hr}$ ), methyl red (MR) reaction (after $48 \mathrm{hr}$ ), Cook's (1950) modification of the nitrate-reduction test, VogesProskauer (V-P) test (after $48 \mathrm{hr}$ ), utilisation of citrate in Simmons' citrate medium (Difco), $o$-nitrophenyl- $\beta$-D-galactopyranosidase (ONPG) test (Cowan and Steel), KauffmannPetersen's (K-P) tests for the fermentation of the organic acids citrate and mucate (original method as modified by Ellis, Edwards and Fife, 1957), the appearance of visible turbidity

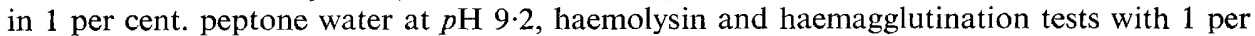
cent. sheep red cells (Barua and Mukherjee, 1964, 1965). Gelatin degradation was tested for by the method of Smith and Goodner. For determination of antibiograms, the conventional agar-diffusion method was employed with " Multodisks" (Oxoid) placed on a dried seeded plate of Mueller-Hinton (Difco) medium. The disks separately held $10 \mu \mathrm{g}$ each of chloramphenicol, tetracycline and streptomycin, $25 \mu \mathrm{g}$ of ampicillin, $5 \mu \mathrm{g}$ kanamycin and 100 units of polymyxin B. Disks containing 50 units of polymyxin B (Difco) were also used separately. Sensitivity to 2,4-diamino-6,7-diisopropyl pteridine ("Vibriostatin" 0/129 supplied by Allen and Hanbury Ltd, Ware, Herts, England) was tested on nutrient agar plates with crystals of the reagent (Shewan, Hodgkiss and Liston, 1954). The sensitivity of the strains to Mukerjee's (1963) cholera group-IV phage was also tested.

\section{RESULTS}

Non-cholera vibrios (NCV) of Heiberg groups (HG) II, I and VII were isolated more frequently than NCV of the other groups, and no HG-III and HG-IV strains were obtained during this investigation (table I). Each patient yielded only one biotype of NCV, though this differed from one case to another. 
TABLE II

Results produced by the NCV of different Heiberg groups $(H G)$ in various tests

\begin{tabular}{|c|c|c|c|c|c|c|c|c|}
\hline \multirow{2}{*}{\multicolumn{2}{|c|}{ Test }} & \multicolumn{6}{|c|}{$\begin{array}{c}\text { Number of strains of the stated group giving positive test } \\
\text { results* }\end{array}$} & \multirow{2}{*}{$\begin{array}{l}\text { Total } \\
\text { number } \\
\text { positive }\end{array}$} \\
\hline & & $\begin{array}{l}\mathrm{HG} \mathrm{I} \\
(14)\end{array}$ & $\begin{array}{l}\text { HG II } \\
(16)\end{array}$ & $\begin{array}{l}\mathrm{HG} \mathrm{V} \\
(2)\end{array}$ & $\begin{array}{l}\text { HG VI } \\
\text { (1) }\end{array}$ & $\begin{array}{l}\mathrm{HG} \text { VII } \\
(13)\end{array}$ & $\begin{array}{l}\text { HG VIII } \\
\text { (1) }\end{array}$ & \\
\hline $\begin{array}{l}\text { String test } \\
\text { Stability in saline : } \\
\text { Stability in acriflavine : } \\
\text { Gelatin degradation } \\
\text { Nitrate reduction. } \\
\text { Indole production } \\
\text { Methyl red (MR). } \\
\text { Voges-Proskauer (V-P) }\end{array}$ & : & $\begin{array}{r}14 \\
14 \\
14 \\
14 \\
11 \\
14 \\
3 \\
11\end{array}$ & $\begin{array}{r}16 \\
16 \\
16 \\
15 \\
13 \\
16 \\
2 \\
13\end{array}$ & $\begin{array}{l}2 \\
2 \\
2 \\
2 \\
2 \\
2 \\
1 \\
0\end{array}$ & $\begin{array}{l}1 \\
0 \\
0 \\
0 \\
0 \\
1 \\
1 \\
0\end{array}$ & $\begin{array}{r}12 \\
10 \\
4 \\
13 \\
13 \\
6 \\
0 \\
0\end{array}$ & $\begin{array}{l}1 \\
1 \\
1 \\
1 \\
1 \\
0 \\
0 \\
0\end{array}$ & $\begin{array}{r}46 \\
43 \\
37 \\
45 \\
40 \\
39 \\
7 \\
24\end{array}$ \\
\hline Simmons' citrate utilisation & . & 13 & 15 & 1 & 0 & 0 & 0 & 29 \\
\hline $\begin{array}{l}\text { Fermentation of organic ac } \\
\text { tests): } \\
\text { citrate } \\
\text { mucate }\end{array}$ & $\begin{array}{r}\text { ds }(\mathrm{K}-\mathrm{P} \\
. \\
.\end{array}$ & $\begin{array}{l}14 \\
14\end{array}$ & $\begin{array}{l}15 \\
10\end{array}$ & $\begin{array}{l}2 \\
1\end{array}$ & $\begin{array}{l}0 \\
0\end{array}$ & $\begin{array}{l}0 \\
0\end{array}$ & $\begin{array}{l}0 \\
0\end{array}$ & $\begin{array}{l}31 \\
25\end{array}$ \\
\hline ONPG & . & 14 & 16 & 2 & 1 & 0 & 0 & 33 \\
\hline 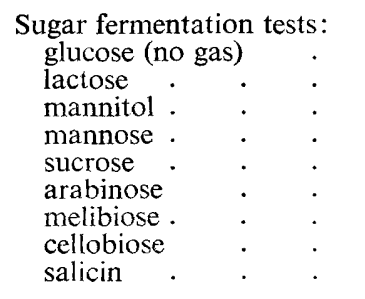 & $\begin{array}{ll}\cdot & : \\
: & : \\
: & : \\
: & : \\
: & : \\
: & :\end{array}$ & $\begin{array}{r}14 \\
11 \\
14 \\
14 \\
14 \\
0 \\
0 \\
3 \\
0\end{array}$ & $\begin{array}{r}16 \\
15 \\
16 \\
0 \\
16 \\
0 \\
0 \\
0 \\
0\end{array}$ & $\begin{array}{l}2 \\
2 \\
2 \\
2 \\
0 \\
0 \\
0 \\
0 \\
1\end{array}$ & $\begin{array}{l}1 \\
0 \\
1 \\
0 \\
0 \\
0 \\
0 \\
0 \\
0\end{array}$ & $\begin{array}{r}13 \\
0 \\
13 \\
13 \\
0 \\
13 \\
2 \\
0 \\
0\end{array}$ & $\begin{array}{l}1 \\
0 \\
1 \\
0 \\
0 \\
1 \\
0 \\
1 \\
0\end{array}$ & $\begin{array}{r}47 \\
28 \\
47 \\
29 \\
30 \\
14 \\
2 \\
4 \\
1\end{array}$ \\
\hline $\begin{array}{l}\text { Pellicle formation } \\
\text { Haemagglutination } \\
\text { Haemolysin production. }\end{array}$ & $\dot{.}$ & $\begin{array}{r}13 \\
9 \\
9\end{array}$ & $\begin{array}{r}12 \\
12 \\
9\end{array}$ & $\begin{array}{l}1 \\
0 \\
1\end{array}$ & $\begin{array}{l}0 \\
0 \\
1\end{array}$ & $\begin{array}{l}0 \\
2 \\
0\end{array}$ & $\begin{array}{l}0 \\
0 \\
0\end{array}$ & $\begin{array}{l}26 \\
23 \\
20\end{array}$ \\
\hline $\begin{array}{l}\text { Decarboxylase reactions: } \\
\text { arginine }: \\
\text { lysine } \\
\text { ornithine }\end{array}$ & $\dot{.}$ & $\begin{array}{r}0 \\
14 \\
14\end{array}$ & $\begin{array}{r}0 \\
16 \\
16\end{array}$ & $\begin{array}{l}0 \\
2 \\
2\end{array}$ & $\begin{array}{l}0 \\
1 \\
1\end{array}$ & $\begin{array}{r}0 \\
13 \\
11\end{array}$ & $\begin{array}{l}0 \\
1 \\
1\end{array}$ & $\begin{array}{r}0 \\
47 \\
45\end{array}$ \\
\hline $\begin{array}{l}\text { Antibiotic resistance tests: } \\
\text { chloramphenicol }(10 \mu \mathrm{g}) \\
\text { tetracycline }(10 \mu \mathrm{g}) \\
\text { streptomycin }(10 \mu \mathrm{g}) \\
\text { ampicillin }(25 \mu \mathrm{g}) \\
\text { kanamycin }(5 \mu \mathrm{g}) \\
\text { polymyxin } \mathrm{B}(100 \text { units }) \\
\text { polymyxin } \mathrm{B}(50 \text { units) }\end{array}$ & $\begin{array}{l}\dot{5} \\
\dot{5} \\
\dot{.}\end{array}$ & $\begin{array}{l}0 \\
0 \\
1 \\
0 \\
1 \\
0 \\
9\end{array}$ & $\begin{array}{r}0 \\
1 \\
2 \\
3 \\
0 \\
0 \\
0 \\
10\end{array}$ & $\begin{array}{l}0 \\
1 \\
0 \\
1 \\
0 \\
0 \\
1\end{array}$ & $\begin{array}{l}0 \\
0 \\
0 \\
0 \\
0 \\
0 \\
0 \\
0\end{array}$ & $\begin{array}{r}0 \\
0 \\
0 \\
13 \\
0 \\
0 \\
0\end{array}$ & $\begin{array}{l}0 \\
0 \\
0 \\
0 \\
0 \\
0 \\
0\end{array}$ & $\begin{array}{r}0 \\
2 \\
3 \\
17 \\
1 \\
0 \\
20\end{array}$ \\
\hline
\end{tabular}

* Figures in brackets indicate total numbers of strains tested. 
All 47 strains were Gram-negative motile rods, giving positive results in tests for oxidase and catalase, producing acid without gas in fermentation tests with glucose and mannitol, giving positive decarboxylase test results with lysine but negative with arginine, and sensitive to "Vibriostatin " $0 / 129$. The organisms belong to the genus Vibrio and, being inagglutinable with $V$. cholerae $\mathrm{O}$-subgroup I antiserum, were regarded as $\mathrm{NCV}$.

TABLE III

Comparison of the biochemical reactions of NCV strains isolated in three investigations

\begin{tabular}{|c|c|c|c|c|c|c|}
\hline \multirow{3}{*}{ Test } & \multicolumn{6}{|c|}{ Results of tests reported in the series of } \\
\hline & \multicolumn{2}{|c|}{$\begin{array}{l}\text { McIntyre and Feeley } \\
\text { (1965) } 69 \text { strains }\end{array}$} & \multicolumn{2}{|c|}{$\begin{array}{l}\text { Sakazaki et al. } \\
\text { (1967) } 118 \text { strains }\end{array}$} & \multicolumn{2}{|c|}{$\begin{array}{l}\text { Present study } \\
\text { (1967) } 47 \text { strains }\end{array}$} \\
\hline & $\begin{array}{l}\text { Number } \\
\text { positive }\end{array}$ & $\begin{array}{l}\text { Number } \\
\text { negative }\end{array}$ & $\begin{array}{l}\text { Number } \\
\text { positive }\end{array}$ & $\begin{array}{l}\text { Number } \\
\text { negative }\end{array}$ & $\begin{array}{l}\text { Number } \\
\text { positive }\end{array}$ & $\begin{array}{l}\text { Number } \\
\text { negative }\end{array}$ \\
\hline $\begin{array}{l}\text { Oxidase } \\
\text { O-F test (fermentative) } \\
\mathrm{H}_{2} \mathrm{~S} \text { production } \\
\text { Indole production } \\
\text { Haemolysin production }\end{array}$ & $\begin{array}{r}69 \\
69 \\
0 \\
68 \\
68\end{array}$ & $\begin{array}{r}0 \\
0 \\
69 \\
1 \\
1\end{array}$ & $\begin{array}{r}118 \\
118 \\
0 \\
118 \\
117\end{array}$ & $\begin{array}{r}0 \\
0 \\
118 \\
0 \\
1\end{array}$ & $\begin{array}{r}47 \\
47 \\
0 \\
39 \\
20\end{array}$ & $\begin{array}{r}0 \\
0 \\
47 \\
8 \\
27\end{array}$ \\
\hline $\begin{array}{l}\text { Fermentation of organic } \\
\text { acids (K-P tests): } \\
\text { citrate } \\
\text { mucate }\end{array}$ & $\begin{array}{l}\ldots \\
\cdots\end{array}$ & $\begin{array}{l}\ldots \\
\ldots\end{array}$ & $\begin{array}{l}117 \\
118\end{array}$ & $\begin{array}{l}1 \\
0\end{array}$ & $\begin{array}{l}31 \\
25\end{array}$ & $\begin{array}{l}16 \\
22\end{array}$ \\
\hline $\begin{array}{l}\text { Decarboxylase reactions: } \\
\text { lysine } \\
\text { ornithine }\end{array}$ & $\begin{array}{l}65 \\
65\end{array}$ & $\begin{array}{l}4 \\
4\end{array}$ & $\begin{array}{l}117 \\
117\end{array}$ & $\begin{array}{l}1 \\
1\end{array}$ & $\begin{array}{l}47 \\
45\end{array}$ & $\begin{array}{l}0 \\
2\end{array}$ \\
\hline $\begin{array}{c}\text { Sugar fermentation } \\
\text { reactions: } \\
\text { lactose } \\
\text { melibiose : } \\
\text { cellobiose : } \\
\text { arabinose : } \\
\text { sucrose }:\end{array}$ & $\begin{array}{l}48 \\
\cdots \\
\cdots \\
4 \\
66\end{array}$ & $\begin{array}{l}21 \\
\cdots \\
\ldots \\
65 \\
3\end{array}$ & $\begin{array}{r}118 \\
0 \\
29 \\
0 \\
115\end{array}$ & $\begin{array}{r}0 \\
118 \\
89 \\
118 \\
3\end{array}$ & $\begin{array}{r}28 \\
2 \\
4 \\
14 \\
30\end{array}$ & $\begin{array}{l}19 \\
45 \\
43 \\
33 \\
17\end{array}$ \\
\hline
\end{tabular}

The majority of the HG-I and HG-II strains fermented lactose and gave positive results in the indole, V-P, ONPG, Simmons' citrate and K-P organic acid tests; NCV of HG VII all gave negative results in these tests. This distinction could also be made according to the presence or absence of a pellicle (table II). Pellicles appeared either in flimsy or membranous forms; five of the HG-I strains, eight of HG-II, and one of HG-V produced membranous pellicles, and the other pellicles were of the flimsy variety. More than half of the HG-I and HG-II NCV revealed haemolytic and haemagglutinating properties that were not possessed by HG-VII organisms. Unlike the other NCV, those of HG VII produced a faint purplish discoloration in the control tube set up for the decarboxylase test. Two strains of HG VII were ornithine decarboxylase-negative; a single strain in the same group gave a negative string test. Nine of the $13 \mathrm{HG}$-VII strains produced rough colonies as judged by their reactions in slide tests with saline or acriflavine. In tests of all of the NCV isolated in the present study, acid production was rarely observed in salicin, melibiose or cellobiose. Results of fermentation tests with dulcitol, inositol, sorbitol, rhamnose and raffinose were 
always negative. All NCV were phage IV-resistant. Some of the biochemical reactions recorded for $\mathrm{NCV}$ in the present investigation are summarised and compared with those obtained by other investigators in table III.

\section{Discussion}

In the present study, the non-cholera vibrio (NCV) group was distinguished from Enterobacteriaceae by a positive oxidase reaction, from $P$ seudomonas by the fermentative breakdown of glucose in O-F medium and inhibition by "Vibriostatin " $0 / 129$. NCV were distinguished from Comamonas by their ability to attack glucose. Aeromonas and Plesiomonas were ruled out by the results of the decarboxylase tests.

Many of our findings are similar to those of other workers (see table III), but the frequency of haemolytic strains appears to be significantly less in the present work. This is probably attributable to the total exclusion of NCV of HG VII from the other two studies. Furthermore, the distinction between haemodigestion and true haemolysis is often not evident with the plate test for haemolysis that has been employed by other workers (McIntyre and Feeley, 1965; Sakazaki, Gomez and Sebald, 1967). We avoided this pitfall by adopting the special procedure of Barua and Mukherjee (1964). Inclusion of HG-VII organisms should similarly account for the smaller proportion of K-P organic acid-positive strains.

The HG classification of our NCV isolates provided potentially useful information. $\mathrm{NCV}$ of HG I and HG II resemble each other in fermenting lactose and in giving positive reactions in the MR, V-P, Simmons' citrate, and K-P organic acid fermentation tests; on the other hand, HG-VII strains gave negative results in all these tests. The HG-I and HG-II strains appear to be biochemically active and may be related to each other, whereas NCV of group VII are biochemically inactive. Moreover, HG-VII organisms do not produce pellicle or a haemolysin and are sensitive to polymyxin B (50 units). The HG-VII strains are notably resistant to ampicillin $(25 \mu \mathrm{g})$. These features may serve as useful markers for the detection and tracing of $\mathrm{NCV}$.

\section{SUMMARY}

Forty-seven non-cholera vibrios (NCV) isolated from patients admitted to a Calcutta hospital with acute diarrhoea were investigated. Most of the strains belonged to Heiberg groups (HG) I, II and VII. A detailed biochemical study proved that organisms allocated to HG I and II are related to each other in sharing many biochemical activities, whereas NCV of HG VII are biochemically inactive. The HG-VII strains were characterised by their instability in saline or acriflavine or in both, lack of pellicle formation, and resistance to $25 \mu \mathrm{g}$ of ampicillin; they gave negative reactions in lactose fermentation tests and in the ONPG, Simmons' citrate, K-P organic acid fermentation, V-P, and haemolysin tests.

The authors wish to thank Professor J. B. Chatterjea, Director, School of Tropical Medicine, Calcutta, for his kind help during this investigation. The technical assistance of the late Mr B. R. Roy Chowdhury and Mr S. R. Sen Gupta is appreciated. Mr W. A. Cox of Allen and Hanbury Ltd, Ware, Herts, England, kindly supplied the sample of Vibriostatin $0 / 129$.

\section{REFERENCES}

Aldová, Eva, LázinčKová, Karla, 1968. J. Infect. Dis., 118, 25.

ŠtěPÁnKová, EVA, AND LIETAVA, J.

Barua, D., and Mukherjee, A. C. - 1964. Bull. Calcutta Sch. Trop. Med. Hyg., 12, 100.

", Carpenter, C. C. J., Mitra, P. P., SACK,
R. B., ANd Barua, D.

1965. Bull. Calcutta Sch. Trop. Med. Hyg., 13, COOK, G. T.

1950. J. Clin. Path., 3, 359.

Cowan, S. T., ANd Steel, K. J. . 1966. Manual for the identification of medical bacteria, Cambridge, pp. 158, 160 and 162. 
Crutckshank, R. . . . . . . . 1965. Medical microbiology, 11th ed., Edin-

Ellis, R. J., Edwards, P. R., AND Fife, 1957. Publ. Hlth Lab., 15, 89. MARY A.

HeiberG, B. . . . . . . . . . . . 1936. J. Hyg., Camb., 36, 114.

Hugh, R., AND LeIrson, E. - . . . . 1953. J. Bact., 66, 24.

Kovacs, N. . . . . . . . . . 1956. Nature, Lond., 178, 703.

Lindenbaum, J., Greenough, W. B., III, 1965. Lancet, 1, 1081.

BENENSON, A. S., OsEASOHN, R., Rizvi, S., AND SAAD, A.

McIntyre, O. R., AND Feeley, J. C.

1965. Bull. Wld Hlth Org., 32, 627.

McIntyre, O. R., Feeley, J. C., GreenOUgh, W. B., III, Benenson, A. S., Hassan, S. I., AND SAAD, A.

MøLler, V. .

1965. Amer. J. Trop. Med. Hyg., 14, 412.

MukerJee, S. . . . . . . . . . . .

POllitzer, R. . . . . . . . . . . .

1955. Acta path. microbiol. scand., 36, 158.

1963. Bull. Wld Hlth Org., 28, 337.

1959. Cholera, World Health Organization Monograph Series no. 43.

SaCk, R. B., Barua, D., SAXena, R., AND 1966. J. Infect. Dis., 116, 630.

CARPENTER, C. C. J.

Sakazaki, R., Gomez, Cecilia Z., And 1967. Jap.J. Med. Sci. Biol., 20, 265.

Sebald, Madeleine

SHEWAN, J. M., Hodgkiss, W., AND 1954. Nature, Lond., 173, 208. LISTON, J.

SMITH, H. L., JR . . . . . . . . 1958. Bact. Proc., p. 69.

Smith, H. L., JR, AND Goodner, K. 1965. Proceedings of the Cholera Research Symposium, January 24th-29th, Honolulu, Hawaii, Washington, D.C., p. 4.

Wilson, G. S., And Miles, A. A. 1964. Topley and Wilson's Principles of bacteriology and immunity, 5th ed., London, vol. 1, pp. 336 and 1002 .

\title{
ANTIBODY TO ONCOGENIC VIRUS IN CANCER PATIENTS
}

\author{
E. SANDRA McFarlane* \\ Department of Microbiology, Dalhousie University, Halifax, Nova Scotia, Canada
}

THE discovery that some human adenoviruses are oncogenic for hamsters (Huebner, Rowe and Lane, 1962; Trentin, Yabe and Taylor, 1962) and that animal oncogenic viruses, such as the simian virus SV40, are not necessarily species-specific (Koprowski et al., 1962) led to a search for evidence of infection with these viruses in cancer patients (Larson, Gasnell and Hilleman, 1967; Rowe and Lewis, 1968; Shah, 1969).

In the present study we looked for complement-fixing antibodies against adenovirus type-12 tumour (T) antigen and SV40 tumour (T) antigen in both cancer patients and control subjects. In the hamster adenovirus-tumour model the presence of complement-fixing antibody against $\mathrm{T}$ antigen has been shown to reflect current antigenic stimulation; the antibody level drops on removal of the tumour (Larson et al.). The presence of this antibody in human serum probably indicates, therefore, either recent infection with the virus or a cancerous condition induced by the virus. 